\title{
Genetic Variability in Nicotiana tabacum and Nicotiana Species as Revealed by RAPD Markers: 1. Development of the RAPD Procedure*
}

\author{
by \\ L. del Piano, M. Abet, C. Sorrentino, F. Acanfora, E. Cozzolino, A. Di Muro \\ Istituto Sperimentale per il Tabacco, \\ via P. Vitiello no 66, \\ 84018 Scafati (SA), Italy.
}

\section{SUMMARY}

At present there is no information about the level of genetic variability in N. tabacum and in the Nicotiana genus as revealed by random amplified polymorphic DNA (RAPD). Such knowledge could be useful for taxonomic and breeding purposes. The aim of this paper is to assess the potential application of the DNA polymorphisms generated by RAPD markers within this genus and in tobacco. As rigorously standardized reaction conditions are required to obtain a reproducible RAPD marker, four rapid DNA extraction methods were compared and several parameters of the reaction conditions for the random polymorphic DNA amplification were analysed and optimized. The DNA of six-week-old leaves of $N$. tabacum var. Samsun was obtained with the following methods differing in the strategy of purification: the cetyltrimethylammonium bromide (CTAB) method, that of Edwards, nucleon phytopure system and the method of Goring. Reproducible amplification profiles were obtained with all the methods except for Edwards'. As regards amplification conditions, the effects of primer-template annealing temperature, of a final extension step, of the number of cycles and of the length of extension time in each cycle were analysed. Moreover, the effects on amplification reaction of the DNA amount, of $\mathrm{MgCl}_{2}$, primer and deoxynucleotide triphosphate (dNTP) concentration were evaluated. Then DNA of 12 Nicotiana species and Nicotiana tabacum was amplified with primers OPA-01 and OPA-13 which revealed a considerable polymorphism. The same primers used to analyse 36 var. of $N$. tabacum belonging to different types, showed identical amplification profiles. Further amplification experiments were carried out with only 12 of the tobacco lines; three primers among the 12 assayed revealed one polymorphic fragment each. [Beitr. Tabakforsch. Int. 19 (2000) 1-15]

\section{ZUSAMMENFASSUNG}

Gegenwärtig ist über das Ausmaß der genetischen Variabilität in N. tabacum und in der Gattung Nicotiana, bestimmt durch das random priming-Verfahren RAPD (Random Amplified Polymorphic DNA), nichts bekannt. Diese Information könnte für taxonomische Zwecke und für die Tabakzüchtung nützlich sein. Ziel dieser Arbeit ist es, eine mögliche Anwendung der durch RAPD-Marker erzeugten DNA-Polymorphismen bei der Gattung Nicotiana und beim Tabak zu beurteilen. Da streng standardisierte Reaktionsbedingungen erforderlich sind, um reproduzierbare RAPDMarker zu erhalten, wurden vier Methoden zur schnellen Extraktion der DNA miteinander verglichen und mehrere Parameter der Reaktionsbedingungen der random polymorphen DNA-Amplifikation analysiert und optimiert. Die DNA sechs Wochen alter Tabakblätter von N. tabacum der Varietät Samsun wurde mit Hilfe der nachfolgenden Methoden, die sich in der Art der Reinigung voneinander unterscheiden, gewonnen: 
der Cetyltrimethylammoniumbromid (CTAB)-Methode, der Methode nach Edwards, dem Nucleon Phytopure System und der Methode nach Goring. Reproduzierbare Amplifikationsprofile wurden mit allen Methoden, außer der von Edwards erhalten. Bei den Amplifikationsbedingungen wurden die Auswirkungen der Primerannealing-Temperatur, die Auswirkungen des letzten Extensionsschrittes, der Anzahl der Zyklen und der Dauer der Extensionszeit in jedem einzelnen Zyklus analysiert. Darüber hinaus wurden der Einfluß der DNA-Menge, der $\mathrm{MgCl}_{2}$-Konzentration sowie der Konzentration des verwendeten Primers und der Desoxynucleotidtriphosphate (dNTP) auf die Amplifikationsreaktion bestimmt. Dann wurde die DNA von 12 Nicotiana-Spezies und von N. tabacum mit den Primern OPA-01 und OPA-13 amplifiziert, was das Vorliegen einer beträchtlichen Anzahl von Polymorphismen zeigte. Dieselben Primer, mit denen 36 Varietäten von N. tabacum, die unterschiedlichen Sorten zugerechnet werden, untersucht wurden, ergaben identische Amplifikationsprofile. Weitere Amplifikationsexperimente wurden mit nur 12 Zuchtlinien durchgeführt; drei von 12 untersuchten Primern zeigten jeweils ein polymorphes Fragment. [Beitr. Tabakforsch. Int. 19 (2000) 1-15]

\section{RESUME}

On ne dispose pas actuellement d'informations sur le niveau de la variabilité génétique révélée par l'analyse des profils RAPD chez N. tabacum et le genre Nicotiana. De telles informations pourraient être utiles en taxonomie et en sélection. L'objectif de cette étude est d'évaluer une application potentielle des polymorphismes de l'ADN générés par marqueurs RAPD pour le genre Nicotiana et le tabac (N. tabacum). Les conditions de réaction rigoureusement normalisées étant nécessaires pour obtenir un marqueur RAPD reproductible, quatre méthodes rapides d'extraction d'ADN ont été comparées, et plusieurs paramètres des conditions de la réaction d'amplification aléatoire polymorphe de l'ADN ont été analysés et optimisés. L'ADN de feuilles de N. tabacum var. Samsun âgées de six semaines, a été obtenu en appliquant des méthodes, qui diffèrent dans la stratégie de purification: méthode CTAB (cetyltrimethylammonium bromure), méthode d'Edwards, système Nucleon Phytopure, et méthode de Goring. Des profils d'amplification reproductibles ont été obtenus avec toutes les méthodes sauf celle d'Edwards. Pour les conditions d'amplification, on a analysé les effets de la température d'appariement, l'extension finale, le nombre de cycles de polymérisation et la durée du temps d'extension dans chaque cycle. En outre, on a évalué les effets sur la réaction d'amplification de la quantité d'ADN, de $\mathrm{MgCl}_{2}$ et des concentrations en amorce et en dNTP. Ensuite l'ADN de 12 espèces de Nicotiana et de $N$. tabacum a été amplifié avec les amorces OPA-01 et OPA-13 qui ont révélé un polymorphisme important. Les mêmes amorces, utilisées pour analyser 36 variétés de $N$. tabacum de différents types, ont présenté des profils d'amplification identiques. D'autres essais d'amplification ont été réalisés avec seulement 12 lignées de tabac; trois amorces parmi les 12 testées ont révélé un fragment polymorphe. [Beitr. Tabakforsch. Int. 19 (2000) 1-15]

\section{INTRODUCTION}

Molecular genetic markers have become fundamental tools for plant scientists as they can provide a relatively unbiased method of quantifying genetic diversity in plants (1).

\section{Table 1.}

Tobacco lines examined in this study.

\begin{tabular}{l|l|l}
\hline Burley Bu 49 & Maryland Md 201 & Erzegovina IST E 8A $\left(^{*}\right)$ \\
Burley IST G 14 $\left(^{*}\right)$ & Maryland Md 872 & Erzegovina IST ER 21 \\
Burley IST PS 186 & Maryland Md 609 $\left(^{*}\right)$ & Erzegovina IST E 6B \\
Burley Bu 27 & Kentucky IST T 371 & Perustitza IST Pr 61 $\left(^{*}\right)$ \\
Burley IST 23 $\left(^{*}\right)$ & Kentucky W 39 & Perustitza IST P 2B \\
Burley TN 86 & Kentucky IST T 762 $\left(^{\star}\right)$ & Perustitza IST P 1E \\
Bright IST G 19 $\left(^{*}\right)$ & Havanna IST T 720 $\left(^{*}\right)$ & Samsun Katerini 2/5 $\left(^{\star}\right)$ \\
Bright IST G 9 & Havanna II C & Samsun Katerini 227 \\
Bright IST MS 82 $\left(^{*}\right)$ & Havanna IST 142 & Samsun Katerini 228 \\
Bright Coker 319 & Xanthi IST X 5G & Samsun IST 97 \\
Bright PY 10 & Xanthi IST XR 21 & Samsun T 16 \\
Bright IST G 165 & Xanthi IST X 2H $\left(^{*}\right)$ & Samsun T 1116 $\left(^{*}\right)$ \\
\hline
\end{tabular}

* DNA of all lines were amplified with primers OPA-01 and OPA-13. DNA of lines marked with symbol (*) were also amplified with other arbitrary primers. 
Several methods have been developed such as restriction fragment length polymorphism (RFLP) technology and polymerase chain reaction (PCR) based techniques. RFLPs have been used extensively for genetic studies (2). However this approach is technically complex, costly, time consuming, and requires large amounts of DNA. Over the last few years, PCR technology has had a significant impact on almost all areas of molecular biology and modifications of the basic procedure have allowed the development of numerous assays for detecting variations at the nucleotide level (3). Among them, the technique named random amplified polymorphic DNA $(4,5,6)$, based on PCR amplification of random DNA segments from single arbitrary primers, does not require prior DNA sequence information which is instead necessary for most of the other PCR based assays. Moreover, compared to that of RFLP, RAPD technique is rapid, easy to perform, non radioactive and requires only small amounts of sample DNA. The only disadvantage is that RAPD markers are dominant. This drawback may be overcome in some applications by using more than one closely linked marker (5).

RAPD assay has proved effective in fingerprinting genotypes $(7,8,9)$, in phylogenetic studies $(10,11,12)$, in the identification of markers linked to disease resistance $(13,14,15,16)$, in the generation of linkage maps and in measuring genetic diversity-relatedness in several species $(17,18)$.

In tobacco the RAPD technique has been used mainly to identify markers linked to genes for resistance to pathogens $(19,20,21,22)$, while little information is available about the application of this technique to reveal genetic variability in N. tabacum and in the Nicotiana genus (23), that could be useful for taxonomic and breeding purposes.

The research described in this paper was conducted to optimize the parameters of RAPD assay for tobacco and to assess the potential application of the DNA polymorphisms revealed by RAPD technique within this genus and in tobacco.

\section{MATERIALS AND METHODS}

\section{Plant materials}

In this study 36 tobacco lines (Table 1) and 12 Nicotiana species and Nicotiana tabacum (Samsun line $\mathrm{T}$ 1116) (Table 2) were utilized. All species and lines came from the collection belonging to Istituto Sperimentale per il Tabacco in Scafati, Italy.

Table 2.

Nicotiana species examined in this study

\begin{tabular}{|c|c|c|c|}
\hline Subgenus & Section & Species & $\begin{array}{c}\text { Somatic } \\
\text { chromosome }\end{array}$ \\
\hline \multicolumn{4}{|l|}{ Rustica } \\
\hline & Paniculatae & N. benavidesii & 24 \\
\hline & Rusticae & N. rustica & 48 \\
\hline \multicolumn{4}{|l|}{ Tabacum } \\
\hline & Tomentosae & N. glutinosa & 24 \\
\hline & Genuinae & N. tabacum* & 48 \\
\hline \multicolumn{4}{|l|}{ Petunioides } \\
\hline & Alatae & N. alata & 18 \\
\hline & Suaveolentes & N. debneyi & 48 \\
\hline & & N. amplexicaulis & 36 \\
\hline & & N. velutina & 32 \\
\hline & & N. occidentalis & 42 \\
\hline & & N. simulans & 40 \\
\hline & & N. megalosiphon & 40 \\
\hline & & N. rotundifolia & 44 \\
\hline & & N. suaveolens & 32 \\
\hline
\end{tabular}

* Samsun line T1116 


\section{$D N A$ isolation}

DNA was prepared from leaves of six-week-old plants by means of the following methods:

A CTAB method $(24,25)$, partially modified: $100 \mathrm{mg}$ of leaf tissue pulverized with liquid nitrogen were extracted in a polypropylene centrifuge tube containing $100 \mu \mathrm{L}$ of extraction buffer $2 \times$ (Tris- $\mathrm{HCl}$ $100 \mathrm{mM} \mathrm{pH} \mathrm{8.0,} \mathrm{ethylenediaminetetraacetic} \mathrm{acid}$ (EDTA) $20 \mathrm{mM}, \mathrm{NaCl} 1.4 \mathrm{M}$, CTAB $2 \%$ and mercaptoethanol (added just before use) 2\% (w/v)) at $65^{\circ} \mathrm{C}$. Homogenate obtained with a motor driven pestel, was treated with $200 \mu \mathrm{L}$ of extraction buffer 1 $\times$ (Tris- $\mathrm{HCl} 50 \mathrm{mM} \mathrm{pH}$ 8.0, EDTA $10 \mathrm{mM}, \mathrm{NaCl} 0.7$ $\mathrm{M}$, CTAB $1 \%$ and mercaptoethanol $1 \%(\mathrm{v} / \mathrm{v}))$ and incubated at $65{ }^{\circ} \mathrm{C}$ for 30 minutes. $400 \mu \mathrm{L}$ of chloroform/isoamyl alcohol (24:1) were added at room temperature. After centrifugation for 10 minutes at $16000 \mathrm{~g}$, the supernatant was transferred into a clean tube and treated with 1.5 volumes of precipitation buffer $1 \times$ (Tris-HCl $50 \mathrm{mM} \mathrm{pH} 8.0$, EDTA $10 \mathrm{mM}$, CTAB 1\%, mercaptoethanol 1\% (v/v)). After centrifugation for 5 minutes at $4000 \mathrm{~g}$, the supernatant was discarded and the pellet (CTAB-nucleic acid complex) was solubilized with $200 \mu \mathrm{L}$ of $\mathrm{NaCl} 1 \mathrm{M}$. DNA was precipitated with 2 volumes of cold absolute ethanol for 15 minutes at room temperature and centrifuged for 5 minutes at $4000 \mathrm{~g}$. The pellet was washed with $70 \%$ cold ethanol, air-dried and resuspended in $25 \mu \mathrm{L}$ of TE buffer (tris-[hydroxymethyl]aminomethane hydrochloride $(10 \mathrm{mM})$, ethylendiaminetetraacetic acid $(1 \mathrm{mM}), \mathrm{pH} 8.0)$. The samples were stored at $-20^{\circ} \mathrm{C}$.

B - Edwards method (26)

C Nucleon phytopure system (Amersham Life Science)

DNA was extracted from $100 \mathrm{mg}$ of leaf tissue pulverized with liquid nitrogen, according to the manufacturer's protocol including the presence of $10 \mathrm{mM}$ mercaptoethanol in reagent $\mathrm{A}$ and $\mathrm{RNase}$ digestion $\left(20 \mu \mathrm{g} / \mathrm{mL}\right.$ RNase) for 30 minutes at $37^{\circ} \mathrm{C}$ after addition of reagent $\mathrm{A}$. At the end of the preparation the pellet was resuspended in $25 \mu \mathrm{L}$ of TE buffer $\mathrm{pH}$ 8.0 and stored at $-20^{\circ} \mathrm{C}$.

D - Goring method (27), partially modified

$100 \mathrm{mg}$ of liquid nitrogen pulverized leaf tissue were extracted in a polypropylene centrifuge tube with $400 \mu \mathrm{L}$ of extraction buffer (Tris- $\mathrm{HCl} 50 \mathrm{mM} \mathrm{pH} \mathrm{8.0,}$ EDTA $100 \mathrm{mM}, \mathrm{NaCl} 100 \mathrm{mM}$, sodium dodecyl sulphate (SDS) $1 \%(\mathrm{w} / \mathrm{v})$, mercaptoethanol 1\% (v/v) (added just before use)). The suspension was added with proteinase $\mathrm{K}(0.5 \mathrm{mg} / \mathrm{mL})$ and incubated at $60{ }^{\circ} \mathrm{C}$ for 30 minutes. Then the homogenate was treated with RNase $(280 \mu \mathrm{g} / \mathrm{mL})$ for 30 minutes at $37^{\circ} \mathrm{C}$. After incubation, $400 \mu \mathrm{L}$ of phenol/isoamyl alcohol/chloroform (25:24:1) were added and the mixture was gently shaken for several minutes and centrifuged for 10 minutes at $16000 \mathrm{~g}$. The supernatant was transferred into a fresh tube, treated with an equal volume of cold isopropanol and centrifuged for 5 minutes at $16000 \mathrm{~g}$. The pellet was washed with cold $70 \%$ ethanol, air-dried, resuspended in $25 \mu \mathrm{L} \mathrm{TE}$ buffer $\mathrm{pH} 8.0$ and stored at $-20^{\circ} \mathrm{C}$.

The DNA amount was fluorimetrically quantified using bisBenzimide Hoechst no. 33258 (SIGMA) and

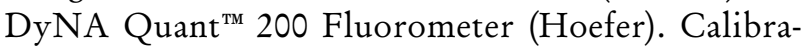
tion was performed using calf thymus DNA (SIGMA) as standard.

$\mathrm{R} A P D-P C R$ assay conditions for the analysis of Nicotiana species and tobacco lines

Primers were obtained from Operon Technologies Inc. $10 \times$ buffer, $\mathrm{MgCl}_{2}, \mathrm{dNTPs}$ and Taq DNA polymerase (AmpliTaq Gold ${ }^{\mathrm{Tm}}$ ) were purchased from Perkin Elmer, gelatine from Boehringer.

The optimized reaction mixture consisted of $20 \mathrm{ng}$ plant DNA and $10 \mathrm{pmol}(0.4 \mu \mathrm{M})$ of primer in $25 \mu \mathrm{L}$ of the following reaction solution: $10 \mathrm{mM}$ Tris- $\mathrm{HCl}$ pH 8.3, $50 \mathrm{mM} \mathrm{KCl}, 2 \mathrm{mM} \mathrm{MgCl}_{2}, 100 \mu \mathrm{M}$ of each dNTP, $0.001 \%$ gelatine and $0.02 \mathrm{U} / \mu \mathrm{L}$ of Taq DNA polymerase. The reaction mixture was warmed in $0.2 \mathrm{~mL}$ polypropylene microtubes (Perkin Elmer) at $94{ }^{\circ} \mathrm{C}$ for 12 minutes then subjected to 45 cycles $\left(94{ }^{\circ} \mathrm{C}\right.$ for $0.5 \mathrm{~min}, 36{ }^{\circ} \mathrm{C}$ for $1 \mathrm{~min}, 72^{\circ} \mathrm{C}$ for $1 \mathrm{~min}$ ) followed by 10 minutes at $72{ }^{\circ} \mathrm{C}$ in a GeneAmp 2400 PCR-DNA thermal cycler (Perkin-Elmer).

\section{Electrophoresis}

Following PCR, the RAPD amplification products were separated by electrophoresis on $1.4 \%$ agarose gel (BIO-RAD) containing ethidium bromide (SIGMA) $(1 \mu \mathrm{g} / \mathrm{mL})$ in TAE buffer (tris-[hydroxymethyl]aminomethane $(40 \mathrm{mM})$, ethylendiaminetetraacetic acid $(1 \mathrm{mM}), \mathrm{pH} 8.0)$, at constant voltage $(5 \mathrm{~V} / \mathrm{cm})$, visualized with UV transilluminator and recorded by photography and by Gel Doc 2000 documentation system (BIO-RAD). $1 \mathrm{Kbp}$ and $100 \mathrm{bp}$ DNA ladder from GIBCO BRL; MM VI from Boehringer, were used as size markers.

Table 3.

Yields of DNA from different extraction procedures.

\begin{tabular}{l|c}
\hline \multicolumn{1}{c|}{ Method } & $\begin{array}{c}\text { Yield } \\
(\mu \mathrm{g} / \mathrm{mg} \text { of fresh tissue })\end{array}$ \\
\hline CTAB method & $278 \pm 40$ \\
Edwards method & $219 \pm 40$ \\
Nucleon phytopure system & $196 \pm 20$ \\
Goring method & $197 \pm 35$ \\
\hline
\end{tabular}

Data represent average \pm standard deviation calculated from three experiments with 10 replications each 


\section{RESULTS}

As rigorously standardized reaction conditions are required to obtain reproducible RAPD profiles, four rapid DNA extraction methods were compared and several parameters of the reaction conditions for the random polymorphic DNA amplification assay were analysed and optimized.

\section{DNA isolation}

Since it is not necessary for the extracted DNA to be of high molecular weight in order to produce moderately sized PCR products (28), several simple and rapid DNA extraction procedures are available, but not all are suitable for RAPD assay, according to the plant source investigated. It is necessary that DNA extracted is devoid of polysaccharides, tannins and other components that can inhibit DNA polymerase activity. Therefore in this study, the following DNA extraction methods were compared for $N$. tabacum utilizing leaves of line Samsun T 1116:

A CTAB method, partially modified

B - Edwards method

C Nucleon phytopure system

D - Goring method, partially modified

These methods differ in the strategy of purification: method A is based on the CTAB procedure, in which a precipitation step combined with chloroform extraction is remarkably effective for eliminating complex carbohydrates; method $\mathrm{B}$ requires only milligram quantities of fresh tissue and purifies DNA by isopropanol precipitation alone; method $\mathrm{C}$ is based on the use of SDS combined with a specially modified resin which binds polysaccharides; method D uses
SDS combined with proteinase $K$ and phenol/chloroform/isoamyl alcohol (25:24:1, saturated with $10 \mathrm{mM}$ Tris $\mathrm{pH} 8,1 \mathrm{mM}$ EDTA) purification step. In Table 3 the DNA yields obtained from the four procedures are reported; they slightly differed in DNA yield, which ranged from $200-280 \mathrm{ng} / \mathrm{mg}$ of fresh tissue. Three DNA preparations from each method were amplified with arbitrary primer OPA-01 according to the procedure reported in the Material and Methods section, to compare electrophoretic profiles. Reproducible RAPD patterns were obtained with the DNA from all the methods. Moreover, identical amplification profiles, consisting of five bands, ranging from 400-1000 bp, were revealed with DNA from the different extraction procedures except for that of Edwards, which showed only three of the five bands and all of low intensity (Figure 1).

\section{$\mathrm{R} A P D-P C R$ parameters optimization}

Because the concentration of template DNA, magnesium chloride, deoxynucleosides triphosphate and primer as well as thermal program conditions have an effect on the amplification profile, it is useful to optimize RAPD-PCR parameters when a new application is performed. The optimization was carried out by successive adjustments of standard RAPD conditions (5) and by taking into account the manufacturers' recommendation for each reagent and for the thermal cycler utilized.

Our experiments to optimize the reaction mixture employed four amounts of DNA template, five concentrations of $\mathrm{MgCl}_{2}$ and six concentrations of deoxynucleosides triphosphate and primer. A summary of

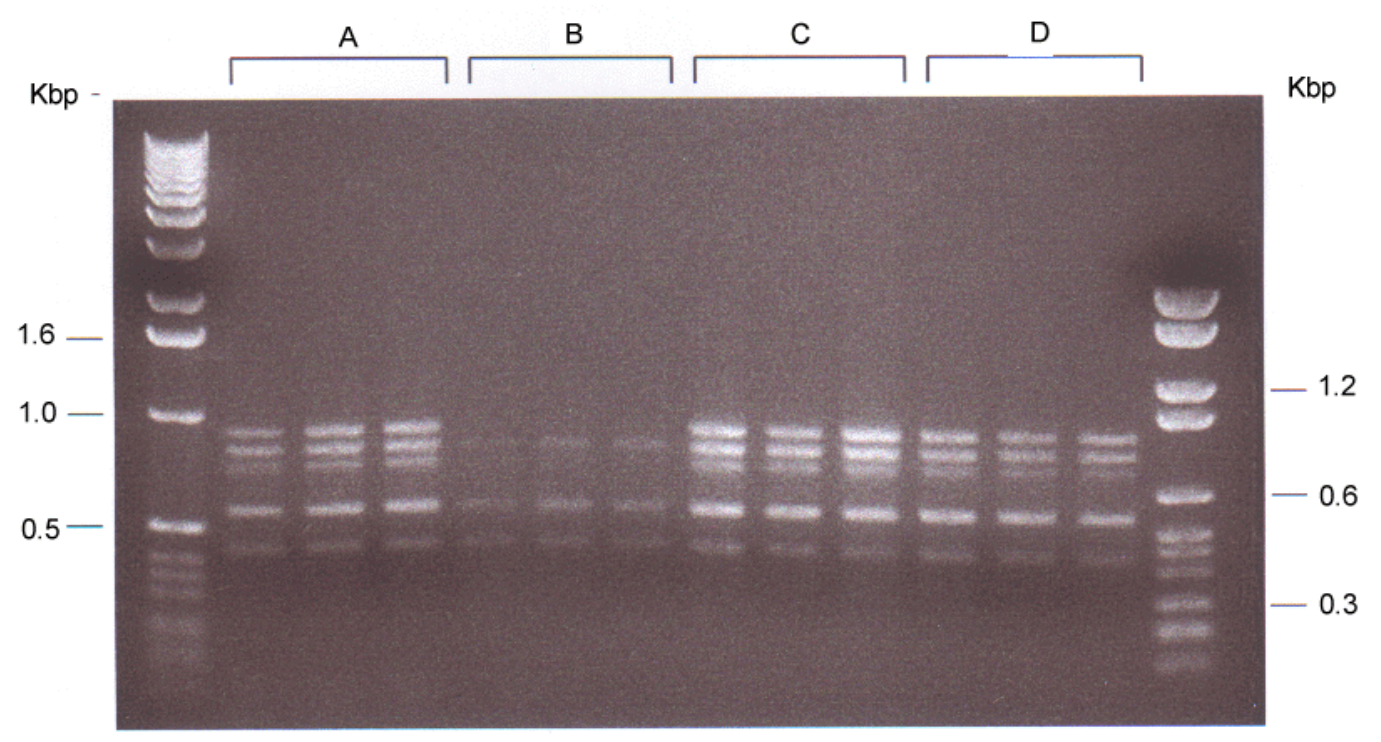

Figure 1.

Amplification patterns obtained with primer OPA-01 of $N$. tabacum T 1116 line DNA extracted with four different methods; $A=C T A B$ method, $B=$ Edwards method, $C=$ Nucleon phytopure system, $D=$ Goring method modified. Three different DNA preparations were amplified for each method. Molecular weight (Kbp) markers are as indicated. 
Table 4.

Evaluated and optimum concentrations for RAPD assay.

\begin{tabular}{l|c|c}
\hline \multirow{2}{*}{ Variable } & \multicolumn{2}{c}{ Concentration } \\
\cline { 2 - 3 } & $20-40-60-80$ & Optimum \\
\hline DNA template $(\mathrm{ng} / 25 \mu \mathrm{L})$ & $1.5-2.0-3.0-4.0-5.0$ & 20 \\
$\mathrm{MgCl}_{2}(\mathrm{mM})$ & $50-100-150-200-250-300$ & 2 \\
$\mathrm{dNTP}(\mu \mathrm{M})$ (each) & $0.2-0.4-0.6-0.8-1.0-1.2$ & 100 \\
Primer $(\mu \mathrm{M})$ &
\end{tabular}
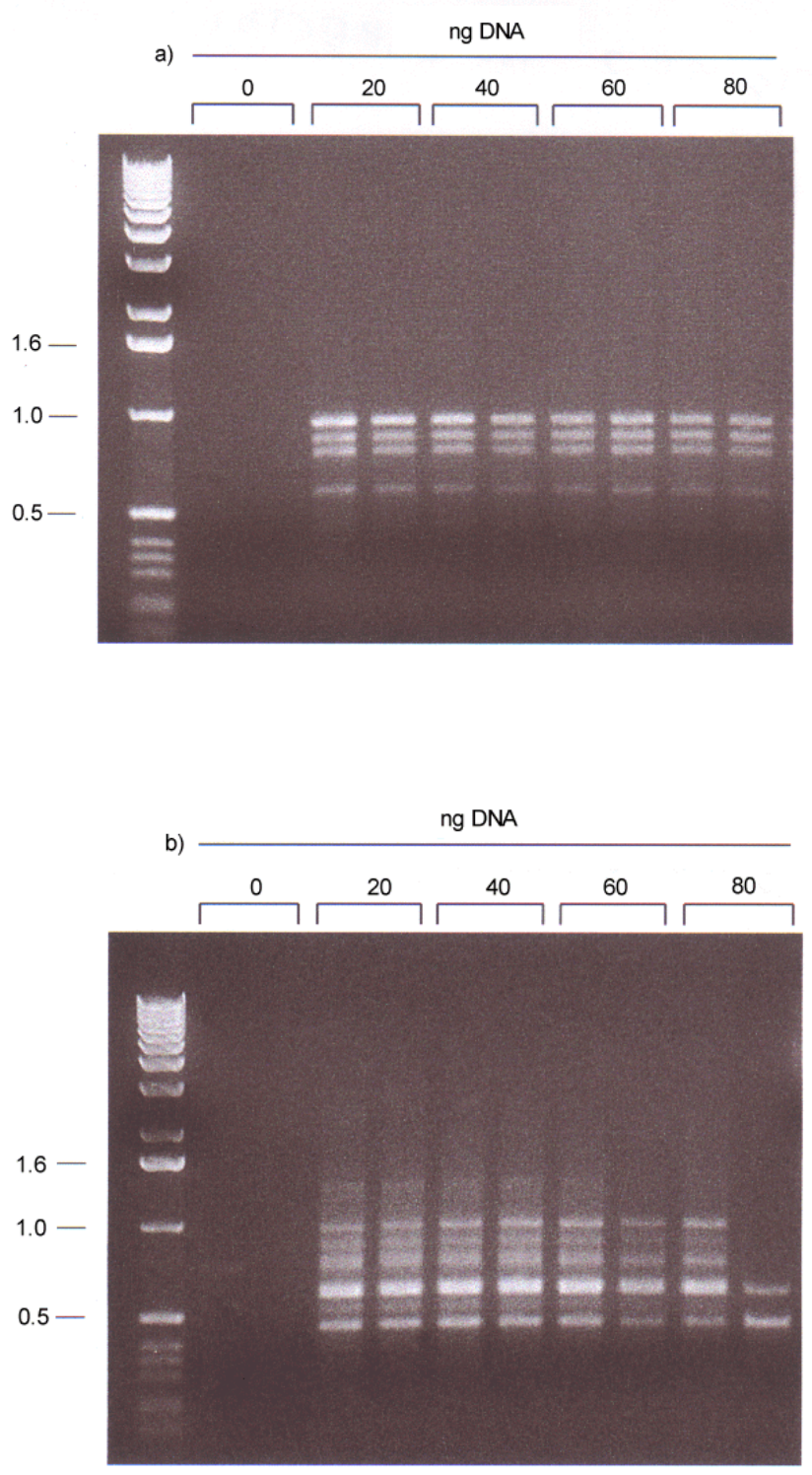

Figure 2.

Effect of different amount of DNA template on amplification pattern. The amplifications were performed with primer OPA-01 (a) and primer OPA-13 (b) in a reaction volume of $25 \mu \mathrm{L}$. Molecular weight $(\mathrm{Kbp})$ markers are as indicated. evaluated concentrations is reported in Table 4. In the same table for each reagent the optimum value revealed by amplification profile analysis obtained with primers OPA-01 and OPA-13 is indicated.

\section{Optimization of DNA concentration}

The increase in DNA amount in the PCR mixture in the range $20-40 \mathrm{ng}$ produced no differences in the patterns, while in the range $60-80 \mathrm{ng}$ it resulted in the disappearance of some bands or in the decrease of their intensity (Figure 2); a further increase in DNA amount resulted in a smear of indistinct bands (data not shown).

\section{Optimization of the magnesium chloride concentration}

As regards $\mathrm{Mg}^{2+}$, concentrations less than $2.0 \mathrm{mM}$ and greater than $3.0 \mathrm{mM}$ caused a loss of bands with respect to patterns observed in the range $2.0-3.0 \mathrm{mM}$ (Figure 3). With primer OPA-13, an increase of the amplification product (about $600 \mathrm{bp}$ ) was also observed (Figure 3b).

Optimization of the deoxynucleosides triphosphate concentration

A deoxynucleoside triphosphate concentration of $100-150 \mu \mathrm{M}$ for each of the four bases gave the best results in amplification profiles, as both at lower and at higher concentrations the intensity of bands became weaker (Figure 4).

Optimization of the primer concentration

As regards the effect of primer concentration, at $0.2 \mu \mathrm{M}$

using OPA-01 it was difficult to detect amplification products, while with OPA-13 fragments, in the range 

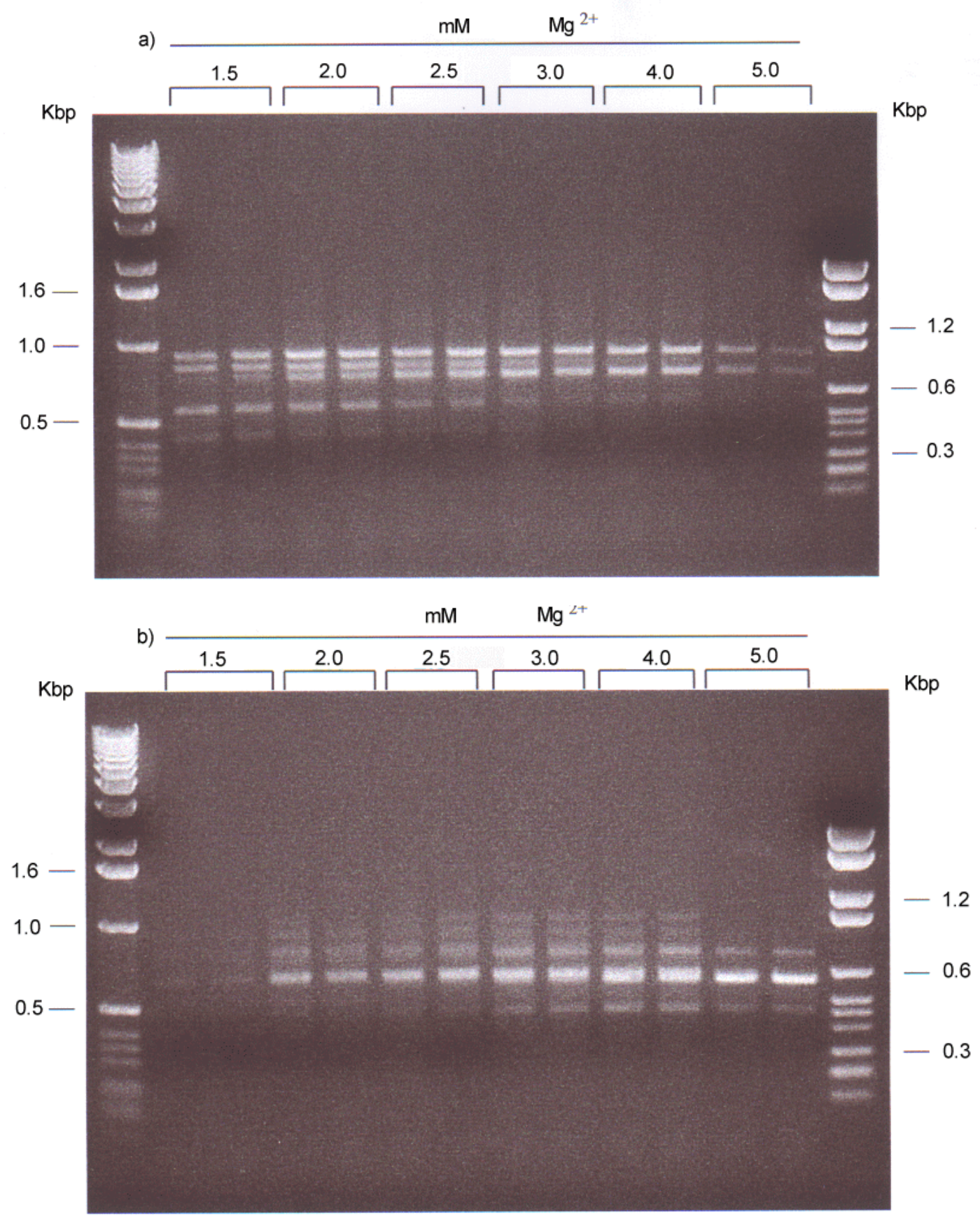

Figure 3.

Effect of magnesium concentration on amplification pattern. The amplifications were performed with primer OPA-01 (a) and primer OPA-13 (b) in a reaction volume of $25 \mu \mathrm{L}$. Molecular weight (Kbp) markers are as indicated.

1.6-1.0 Kbp, which disappeared at higher primer concentrations were noticed. In the range $0.4-1.2 \mu \mathrm{M}$ the increase in the intensity of small amplification products and the loss of some of the largest ones was observed for both primers (Figure 5). A primer concentration of $0.4 \mu \mathrm{M}$ was considered optimal.

\section{Optimization of thermal profile}

The annealing temperature $(\mathrm{Ta})$ is one of most important parameters that affects the relative intensity of amplified bands. Amplification with ten base primers is generally performed between $35-37^{\circ} \mathrm{C}$, and different results might be expected using different thermal cycling instruments. In order to value the effects of $\mathrm{Ta}$ variation in our conditions, four $\mathrm{Ta} 35 ; 36 ; 37 ; 38^{\circ} \mathrm{C}$ were assayed.

For each temperature RAPD-PCR assay was performed with four different primers (OPA-01; OPA-013; OPB-12; OPD-03) and two DNA concentrations (20-40 ng in $25 \mu \mathrm{L}$.). For all primers and both DNA concentrations, slight differences in amplification 

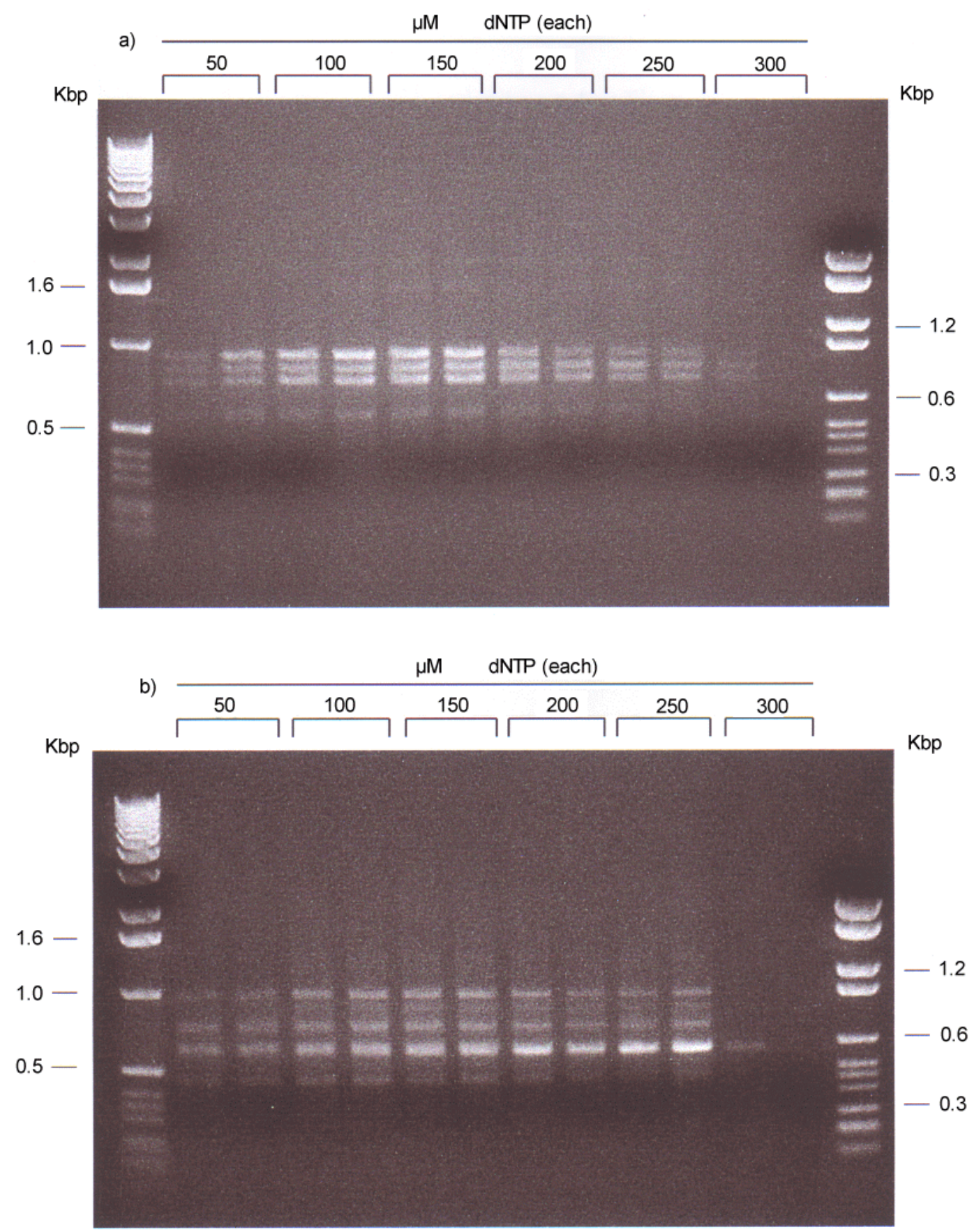

\section{Figure 4.}

Effect of dNTP concentration on amplification pattern. The amplifications were performed with primer OPA-01 (a) and primer OPA-13 (b) in a reaction volume of $25 \mu \mathrm{L}$. Molecular weight (Kbp) markers are as indicated.

patterns were observed between $35^{\circ} \mathrm{C}$ and $37^{\circ} \mathrm{C}$. The same patterns were obtained at $38{ }^{\circ} \mathrm{C}$ Ta but the intensity of some bands decreased.

The effects of the final extension step, the number of cycles and the length of extension time in each cycle were evaluated. The thermal profiles assayed are summarized in Table 5 and the adopted conditions are reported in Table 6 .

As DNA polymerase utilized (AmpliTaq Gold ${ }^{\mathrm{TM}}$ ) is provided in an inactive state, it can be added to the reaction mixture at room temperature without inducing the formation of specific PCR products, so an initial denaturation step 12 minutes long is performed to enable the recovery of enzyme activity. Moreover this step allows the initial complete denaturation of DNA template.

All experiments were conducted by performing RAPD-PCR assays with six primers (OPA-01, OPA - 13, OPB-12, OPD-03, OPE-20 and OPL-17) and the results obtained are shown in Figure 6. The tested PCR thermal profile programs revealed that 

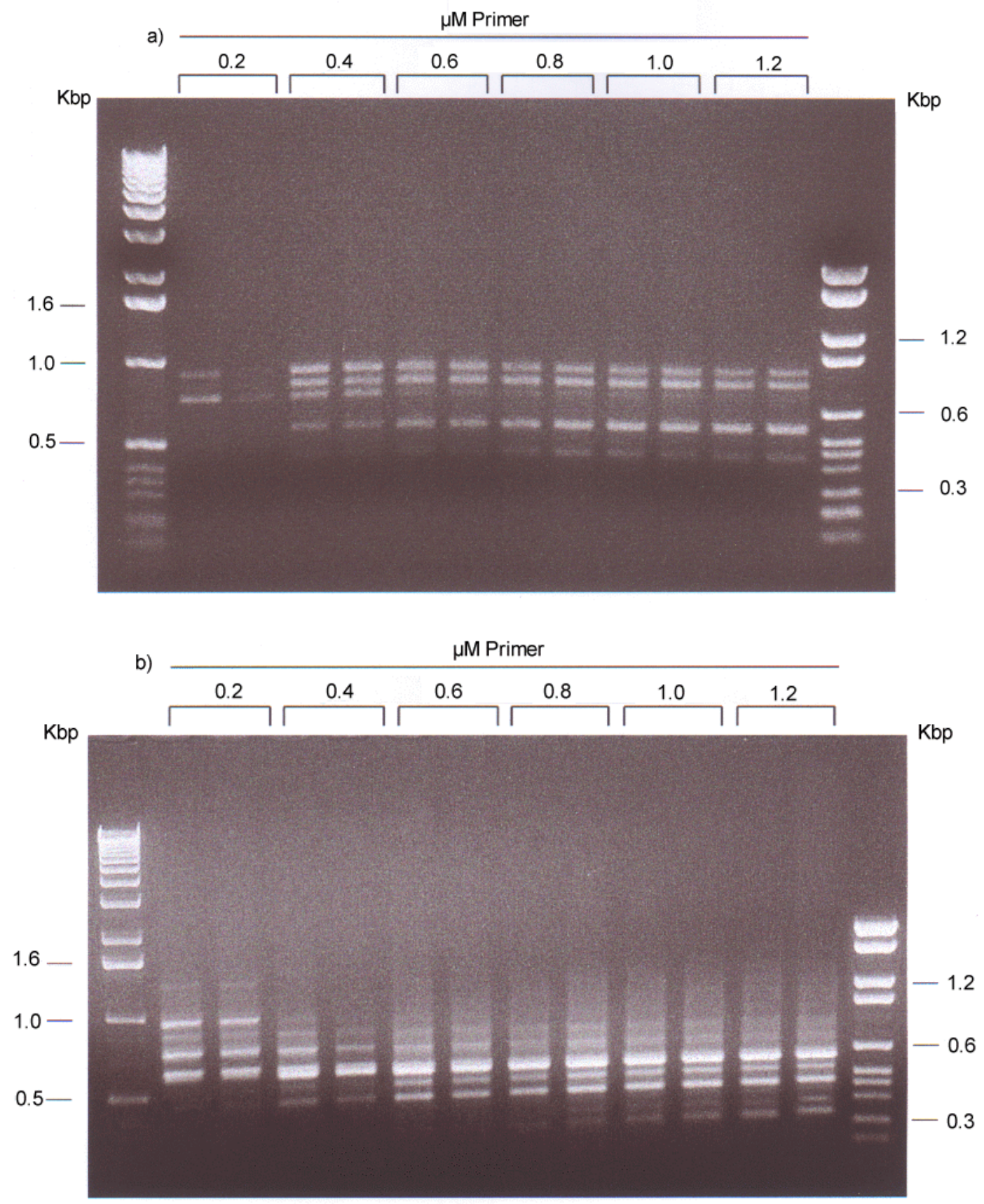

\section{Figure 5.}

Effect of primer concentration on amplification pattern. The amplifications were performed with primer OPA-01 (a) and primer OPA-13 (b) in a reaction volume of $25 \mu \mathrm{L}$. Molecular weight (Kbp) markers are as indicated.

the increase of the primer extension step from 1 to 2 minutes produced remarkable differences in the banding patterns, thus inducing an increase in the intensity of the largest fragments or the appearance of even larger amplification products; a decrease in the intensity of the smallest fragments and a smearing in the banding patterns was often observed.

The variation of the number of cycles from 45 to 55 had no effect on the electrophoretic profile of amplification products, even if a slight increase in the intensity of all fragments was observed. The presence of a final extension step always produced an increase in the intensity of amplified fragments, especially the largest ones.

RAPD-PCR analysis of tobacco and Nicotiana species

DNAs were isolated by means of nucleon phytopure system and amplified according to optimized assay 
Table 5.

PCR thermal profiles assayed.

\begin{tabular}{|c|c|c|c|c|c|}
\hline $\begin{array}{l}\text { Number } \\
\text { of } \\
\text { cycles }\end{array}$ & $\begin{array}{c}\text { Initial } \\
\text { denaturation } \\
94^{\circ} \mathrm{C}\end{array}$ & $\begin{array}{c}\text { Denaturation } \\
94^{\circ} \mathrm{C}\end{array}$ & $\begin{array}{c}\text { Annealing } \\
36^{\circ} \mathrm{C}\end{array}$ & $\begin{array}{c}\text { Extension } \\
72^{\circ} \mathrm{C}\end{array}$ & $\begin{array}{c}\text { Final } \\
\text { extension } \\
72^{\circ} \mathrm{C}\end{array}$ \\
\hline & & & & $1 \mathrm{~min}$ & $0 \mathrm{~min}$ \\
\hline \multirow[t]{3}{*}{45} & $12 \mathrm{~min}$ & $0.5 \mathrm{~min}$ & $1 \mathrm{~min}$ & & $10 \min$ \\
\hline & & & & $2 \mathrm{~min}$ & $0 \mathrm{~min}$ \\
\hline & & & & $1 \mathrm{~min}$ & \\
\hline \multirow[t]{3}{*}{55} & $12 \mathrm{~min}$ & $0.5 \mathrm{~min}$ & $1 \mathrm{~min}$ & & $10 \mathrm{~min}$ \\
\hline & & & & $2 \min$ & $0 \mathrm{~min}$ \\
\hline & & & & & $10 \mathrm{~min}$ \\
\hline
\end{tabular}

conditions reported in the Materials and Methods section.

Tobacco DNA (Samsun T 1116 line) was initially checked using 120 arbitrary primers. Twelve primers failed to amplify DNA, while 98 revealed 424 fragments, corresponding to an average number of bands per primer of 3.5 with a range from 1 to 11 different bands per primer. These amplification products had a size ranging from 0.2 to $2.6 \mathrm{Kbp}$. Primers that produced faint banding patterns or did not reproduce similar banding patterns when replicated at least three times, were not used for further analysis. So a total of 59 primers were selected for the presence of clear and reproducible bands in the amplification profile.

An initial comparative RAPD analysis of genomic DNA extracted from 36 tobacco lines (Table 1) belonging to different types of tobacco was performed, using primers OPA-01 and OPA-13. The amplification profile obtained using these primers did not reveal the presence of polymorphic bands. Further analysis was carried out with only 12 of the tobacco lines (marked with * symbol in Table 1).

Table 6.

Adopted conditions of PCR thermal profile.

\begin{tabular}{cc|c|c|c}
\cline { 2 - 3 } & \multicolumn{3}{c|}{ Cycle (no 45) } & \\
\hline $\begin{array}{c}\text { Initial } \\
\text { denaturation }\end{array}$ & Denaturation & Annealing & Extension & Final extension \\
\hline & & & & \\
$94^{\circ} \mathrm{C}$ & $94^{\circ} \mathrm{C}$ & $36^{\circ} \mathrm{C}$ & $72^{\circ} \mathrm{C}$ & $72^{\circ} \mathrm{C}$ \\
$12 \mathrm{~min}$ & $0.5 \mathrm{~min}$ & $1 \mathrm{~min}$ & $1 \mathrm{~min}$ & $10 \mathrm{~min}$ \\
\hline
\end{tabular}



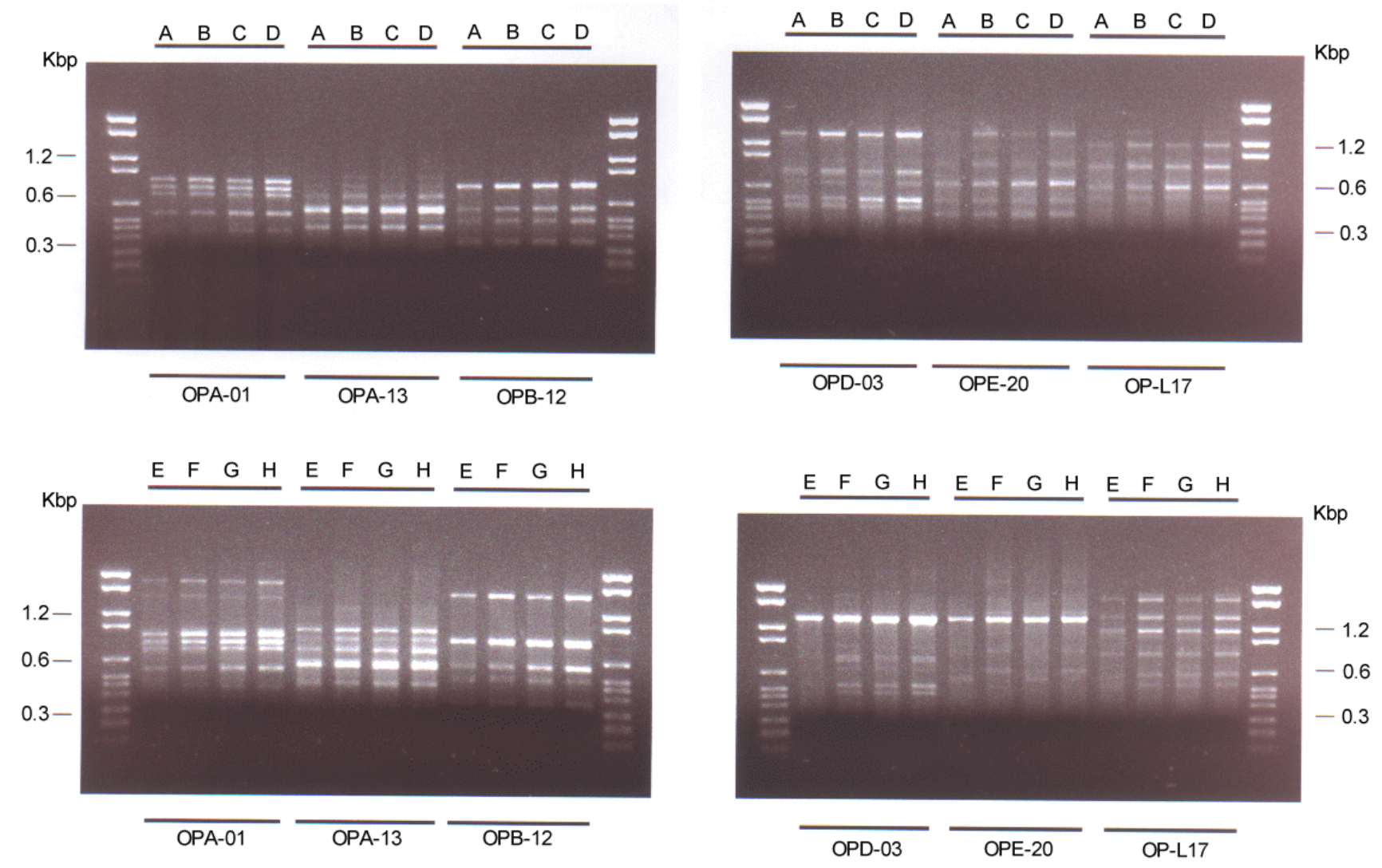

Figure 6.

Amplification profiles obtained with six primers in different PCR thermal programs. Thermal program fixed conditions: Initial denaturation at $94^{\circ} \mathrm{C}$ for $12 \mathrm{~min}$, in the cycle denaturation at $94^{\circ} \mathrm{C}$ for $0.5 \mathrm{~min}$ and annealing at $36{ }^{\circ} \mathrm{C}$ for $1 \mathrm{~min}$. Thermal program variated conditions: 1.) extension time in cycle: $72{ }^{\circ} \mathrm{C}$ for 1 min (lanes $\mathrm{A}-\mathrm{B}-\mathrm{C}-\mathrm{D}$ ), $72{ }^{\circ} \mathrm{C}$ for 2 min (lanes $E-F-G-H)$; 2.) number of cycles: 45 cycles (lanes $A-B, E-F), 55$ cycles (lanes $C-D, G-H)$; 3.) final extension: $72^{\circ} \mathrm{C}$ for 0 min (lanes $A-C ; E-G), 72{ }^{\circ} \mathrm{C}$ for 10 min (lanes B-D, F-H).

Examination of these lines was performed with 12 of the selected primers. Polymorphism was revealed only with primers OPE-20, OPL-07, OPL-17. Each of them evidentiated only one polymorphic band. The amplification pattern obtained with OPE-20 showed an additional fragment of about $750 \mathrm{bp}$, present in Burley IST 23, Bright IST MS 82, Kentucky IST T 762, Xanthi IST X 2H, Perustitza IST Pr 61, Samsun Katerini 2/5 and Samsun T 1116 (Figure 7). In the amplification profiles obtained with OPL-07 a fragment of about 600 bp was absent in Bright IST MS 82 and in Perustitza IST Pr 61 (Figure 8). In the amplification pattern obtained with OPL-17 a band of about 800 bp was absent only in Burley IST G 14 and in Maryland Md 609 (Figure 9).

Comparative RAPD analysis of genomic DNA extracted from 12 Nicotiana species (Table 2) and N. tabacum (Samsun $\mathrm{T}$ 1116) line was performed using primers OPA-01 and OPA-13. Banding patterns of the amplification products obtained are shown respectively in Figures 10 and 11. The primers OPA- 01 and OPA-13 generated, respectively, a total of 17 and 25 amplification products, having a size ranging from 300-1300 bp; for OPA-01 the number of amplified fragments ranged from 2 to 7 while for OPA-13 from 2 to 8 . All 42 amplified products were polymorphic. All examined species showed a different amplification profile with OPA-13, while N. Amplexicaulis, N. velutina and $N$. suaveolens had the same pattern with OPA-01.

\section{DISCUSSION}

The first part of this study dealt with the determination of a RAPD assay protocol suitable for tobacco. Our experiments confirmed the importance of the step related to DNA extraction in a RAPD procedure (9). The Edwards method, although the quickest and the simplest of those compared, could not be used for tobacco, as it gave weak amplification profiles and also lacked some fragments. This result is in accordance with the findings of COUSSIRAT (23) who obtained no amplification bands using tobacco DNA extracted with the Edwards method. It is worth noting that the other 


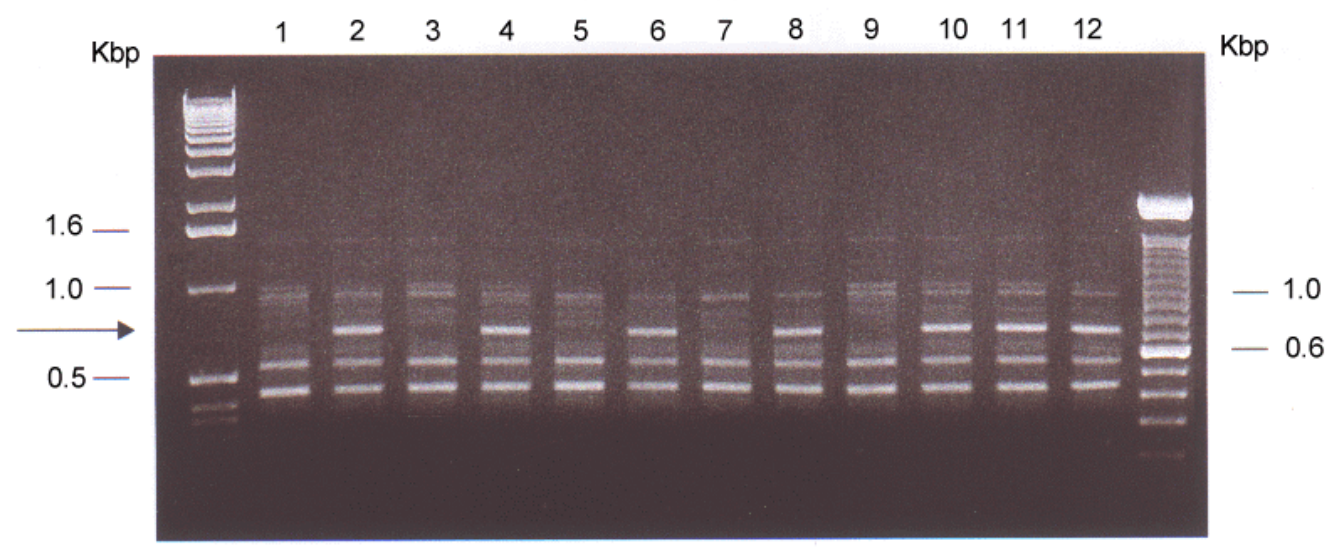

\section{Figure 7.}

RAPD profiles generated by primer OPE-20 with DNAs extracted from 12 tobacco lines. The following lines are included from lane 1 to 12: Burley IST G 14, Burley IST 23, Bright IST G 19, Bright IST MS 82, Maryland Md 609, Kentucky IST T 762 , Havanna IST T 720, Xanthi IST X 2H, Erzegovina IST E 8A, Perustitza IST Pr 61, Samsun Katerini 2/5, Samsun T 1116. The arrow indicates a polymorphic product of about $0.75 \mathrm{Kbp}$.

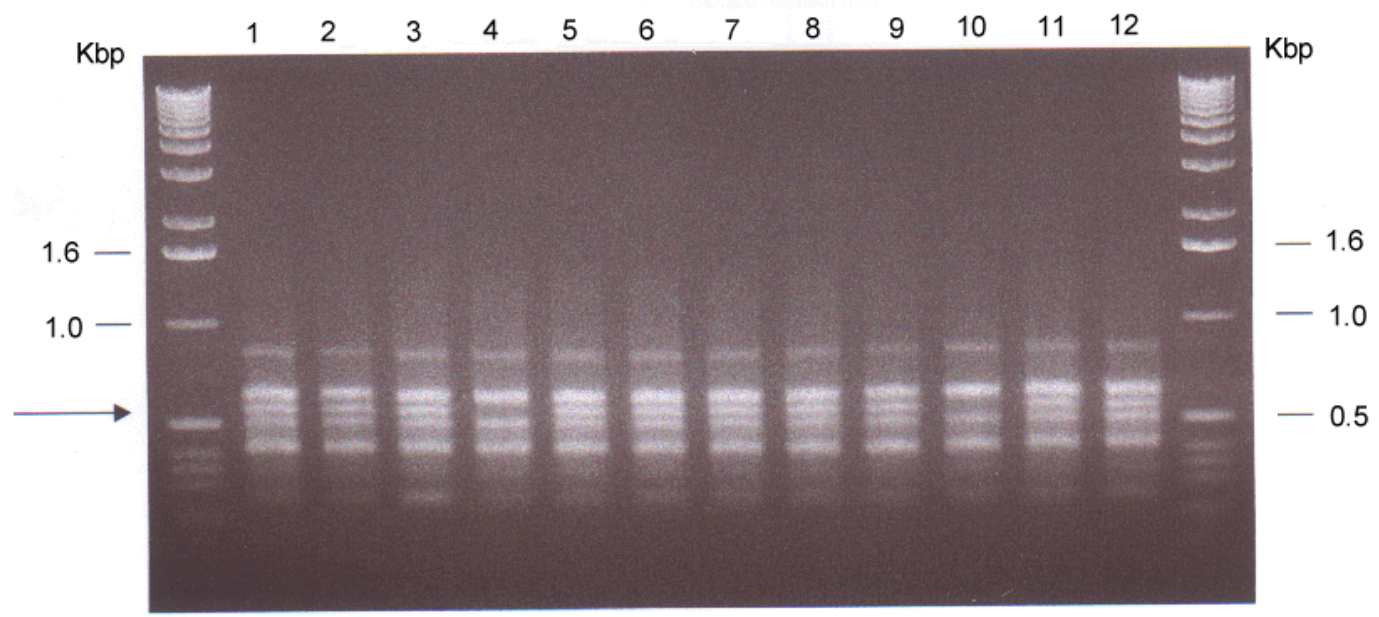

\section{Figure 8.}

RAPD profiles generated by primer OPL- 07 with DNAs extracted from 12 tobacco lines. The following lines are included from lane 1 to 12: Burley IST G 14, Burley IST 23, Bright IST G 19, Bright IST MS 82, Maryland Md 609, Kentucky IST T 762 , Havanna IST T 720, Xanthi IST X 2H, Erzegovina IST E 8A, Perustitza IST Pr 61, Samsun Katerini 2/5, Samsun T 1116. The arrow indicates a polymorphic product of about $0.6 \mathrm{Kbp}$.

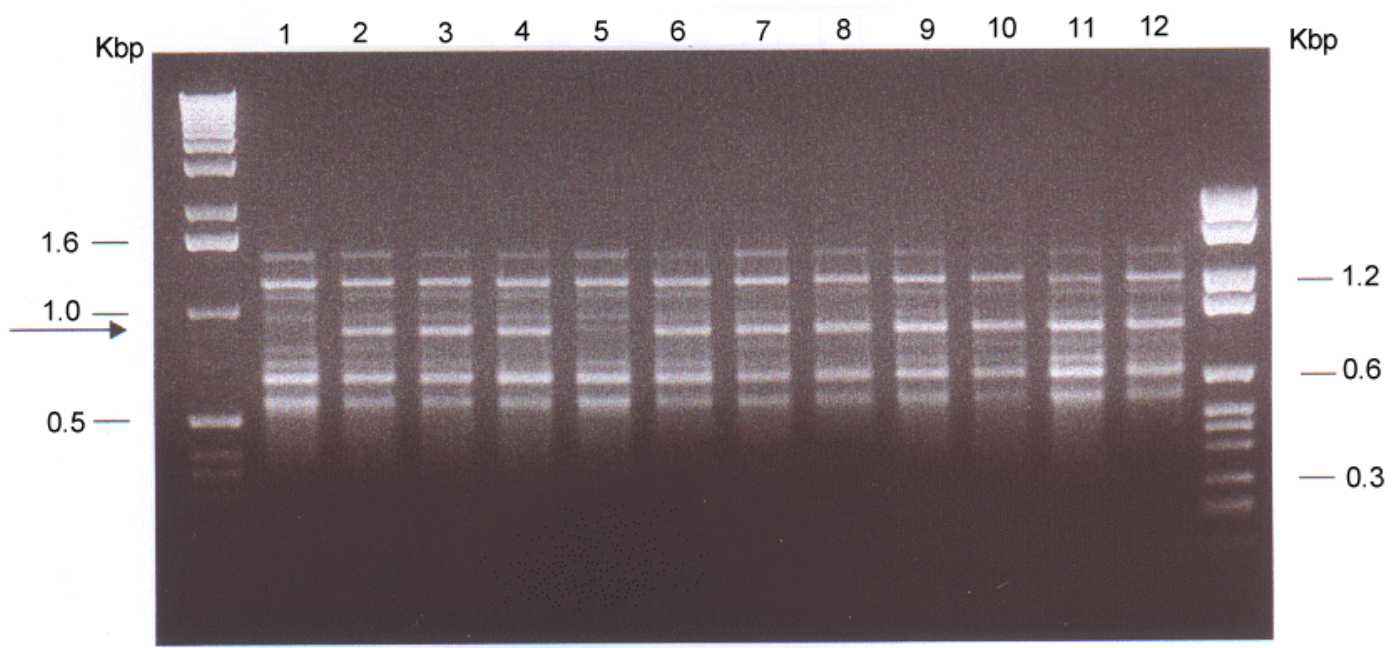

\section{Figure 9.}

RAPD profiles generated by primer OPL-17 with DNAs extracted from 12 tobacco lines. The following lines are included from lane 1 to 12: Burley IST G 14, Burley IST 23, Bright IST G 19, Bright IST MS 82, Maryland Md 609, Kentucky IST T 762 , Havanna IST T 720, Xanthi IST X 2H, Erzegovina IST E 8A, Perustitza IST Pr 61, Samsun Katerini 2/5, Samsun T 1116 . The arrow indicates a polymorphic product of about $0.8 \mathrm{Kbp}$. 


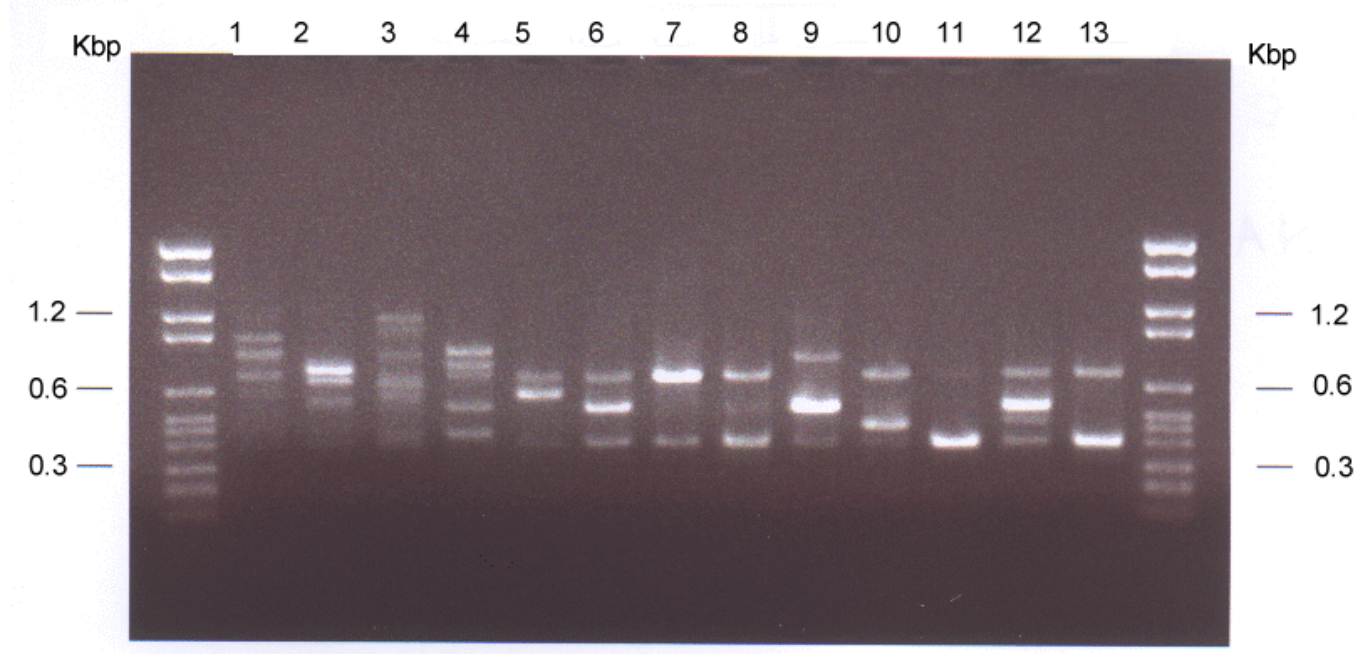

Figure 10.

RAPD profiles generated by primer OPA-01 with DNAs extracted from 13 Nicotiana species. The following species are included from lane 1 to 13: N. benevidesii, N. rustica, N. glutinosa, N. tabacum (Samsun T 1116), N. alata, N. debney, $N$. amplexicaulis, $N$. velutina, $N$. occidentalis, N. simulans, $N$. megalosiphon, $N$. rotundifolia, $N$. suaveolens.

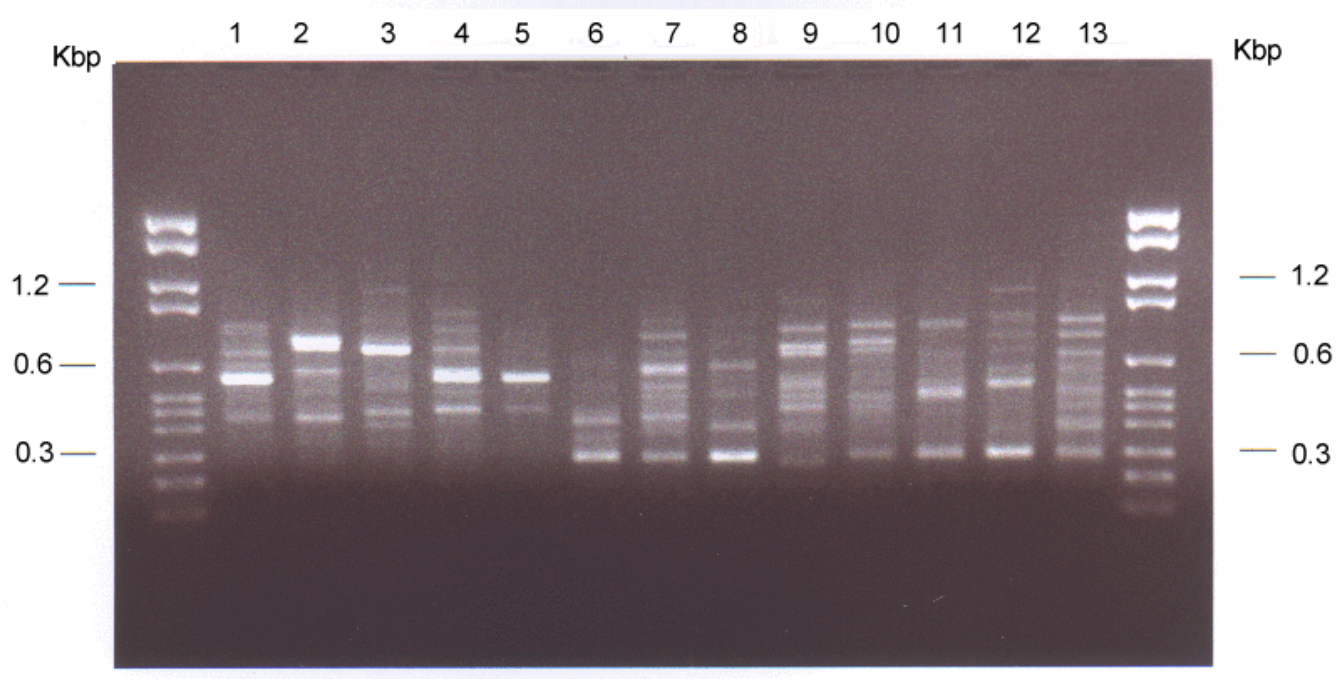

Figure 11.

RAPD profiles generated by primer OPA-13 with DNAs extracted from 13 Nicotiana species. The following species are included from lane 1 to 13: N. benevidesii, N. rustica, N. glutinosa, N. tabacum (Samsun T 1116), N. alata, N. debney, N. amplexicaulis, N. velutina, N. occidentalis, N. simulans, N. megalosiphon, $N$. rotundifolia, $N$. suaveolens.

three methods, though very different in the purification strategy, revealed the same reproducible amplification patterns. We decided to adopt the nucleon phytopure system of DNA extraction in our working protocol as it was quick and simple to use in research programs where large sample throughput is required. Optimum conditions of reagents in the amplification mixture, reported in Table 4, were selected for each component as the lowest concentration which produced reproducible profiles with the highest number of strong bands. Indeed, too much genomic DNA results in smears of bands in the gel (6); an excess of
$\mathrm{Mg}^{2+}$ ions may favour the amplification of aspecific products (29); high concentrations of dNTPs affect the fidelity of DNA polymerase (30); the precise ratio of primer to genomic DNA must be adjusted to avoid the lack of clear amplified bands or a high level of background smear (31).

The effects of DNA, magnesium and dNTP concentrations on amplification profiles, as evaluated in this study, agreed with the findings of WILLIAMS (6), while the effects of primer concentration were in variance. WILLIAMS reported that in the range $0.1-2.0 \mu \mathrm{M}$ the primer concentration had no effect on the relative 
intensities of amplification fragments. Our data revealed in the range $0.4-1.2 \mu \mathrm{M}$ an increase in the intensity of small fragments and the loss of some of the larger ones.

As regards the PCR program, since no differences were observed in banding patterns obtained with four primers in the range $35^{\circ} \mathrm{C}-37^{\circ} \mathrm{C}$, the annealing temperature step at $36{ }^{\circ} \mathrm{C}$ was considered suitable when other primers were screened. For all the primers utilized, no additional information was obtained on banding patterns when the number of cycles was increased from 45 to 55 . Whereas, depending on the primer utilized, the increase of the extension time from 1 to 2 minutes could produce less informative banding patterns as for OPD- 03 and OPE-20,

So the initial conditions of thermal profile, arbitrarily defined by taking account of the standard RAPD procedure by WILLIAMS (5) and the recommendations of the thermal cycler manufacturer, were considered appropriate for carrying out RAPD assay.

Having thus established reproducible working conditions of the RAPD assay, amplification patterns of different tobacco lines and Nicotiana species were compared.

Concerning the intraspecific analysis performed in $N$. tabacum, the preliminary results obtained showed a low polymorphism, as the majority of the amplified fragments in the examined lines were monomorphic. Therefore, a low genetic variability was revealed in tobacco on the basis of random amplified polymorphic DNA and so this technique seemed to be inadequate for N. tabacum variety identification. Nevertheless a low genetic variability revealed by RAPD markers has also been reported for lentil, a predominant self pollinating species like tobacco. Lentil macrosperma and microsperma types had not been differentiated (32) in early studies, but in a subsequent report not only were the two types distinguished, but so were their accessions using additional informative primers (33).

Therefore we maintain that, though a low level of intraspecific polymorphism has been revealed by RAPD technique in this preliminary study, the screening of other carefully selected arbitrary primers is necessary to establish that this technique is not suitable for tobacco line identification and for breeding purposes.

Amplification profiles of the Nicotiana species examined, though obtained with only two primers, reveal a high degree of polymorphism, as all amplified products were polymorphic. On the basis of these preliminary results, it may be expected that RAPD technique is a useful tool to individuate molecular markers able to characterize all Nicotiana species using an appropriate number of primers. The availability of Nicotiana species fingerprints by means of the RAPD technique may contribute to a better characterization of this genus and may be a powerful monitoring tool in maintaining botanic collections.

\section{REFERENCES}

1. Clegg, M.T.: Molecular diversity in plant population; in: Plant population genetics, breeding, and genetic resource, edited by A.H.D. Brown et al., Sinauer Associates, Inc. Sunderland, M.A., 1990, pp. 98-115.

2. Paterson A.H., S.D. Tanksley and M.E. Sorrels: DNA markers in plant improvement; Adv. Agron. 46 (1991) 39-90.

3. Clarke, M.S.: Plant molecular biology. A laboratory manual; Springer Verlag, New York, N.Y., 1997, pp. 305-335.

4. Welsh J. and M. McClelland: Fingerprinting genomes using PCR with arbitrary primers; Nucleic Acids Res. 18 (1990) 7213-7218.

5. Williams J.G.K., A.R. Kubelik, K.J. Livak, J.A. Raflaski and S.V. Tingey: DNA polymorphysms amplified by arbitrary primers are useful as genetic markers; Nucleic Acids Res. 18 (1990) 6531-6535.

6. Williams J.G.K., M.K. Hanafey, J.A. Raflaski and S.V. Tingey: Genetical analysis using random amplified polymorphic DNA markers; Methods Enzymol. 51 (1993) 705-740.

7. Caetano-Anolles G., B.J. Bassam, and P.M. Gresshoff: DNA amplification fingerprint using very short oligonucleotide primers; Bio-Techonology 9 (1991) 553-557.

8. Hu J. and C.F. Quiros: Identification of broccoli and cauliflower cultivars with RAPD markers; Plant Cell Rep. 10 (1991) 505-511.

9. Micheli M.R. and R. Bova: Fingerprinting methods based on arbitrarily primed PCR; Springer-Verlag Berlin Heidelberg, New York, 1997.

10. Halward T.M., H.T. Stalker, E.A. LaRue and G. Kochert: Genetic variation detectable with molecular markers among unadapted germoplasm resources of cultivated peanut and related wild species; Genome 34 (1991) 1013-1020.

11. Demeke T., R.P. Adams and R. Chibbar: Potential taxonomic use of random amplified polymorphic DNA (RAPD). A case study in Brassica; Theor. Appl. Gen. 84 (1992) 990-994.

12. Hoey B.K., K.R. Crowe and V.M. Jones: A phylogenetic analysis of Pisum based on morphological characters, and allozyme and RAPD markers; Theor. Appl. Genet. 92 (1996) 92-100.

13. Haley, S.D., P.N. Miklas, J.R. Stavely, J. Byrum and J.D. Kelly: Identification of RAPD markers linked to a major rust resistance gene block in common bean; Theor. Appl. Gen. 86 (1993) 505-512.

14. Michelmore R.W., I. Paran and R.V. Kesseli: Identification of markers linked to disease resistant genes by bulked segregant analysis: A 
rapid method to detect markers in specific genomic regions using segregating population; Proc. Natl. Acad. Sci. U.S.A. 88 (1991) 9828-9832.

15. Martin, G.B., J.G.K. Williams and S.D. Tanksley: Rapid identification of markers linked to Pseudomonas resistance gene in tomato by using random primers and near-isogenic lines; Proc. Natl. Acad. Sci. U.S.A., 88 (1991) 2336-2340.

16. Lefebvre V. and A.M. Chèvre: Tools for marking plant disease and resistance genes a review; Agronomia Plant Breeding Rev. 15 (1995) 3-19.

17. Tingey S.V and J.P. del Tufo: Genetic analysis with random amplified polymorphic DNA markers; Plant Physiol. 101 (1993) 349-352.

18. Virk P.S., B.V. Ford- Lloyd, M.T. Jackson and H.J. Newbury: Use of RAPD for the study of diversity within plant germplasm collections; Heredity 74 (1995) 170-179.

19. Bai, D., R. Reedler and J.E Brandle: Identification of two RAPD markers tightly linked with the Nicotiana debneyi gene for resistance to black root rot of tobacco; Theor. Appl. Genet. 91 (1995) 1184-1189.

20. Noguchi S., T. Tajima, Y. Yamamoto and T. Kubo: Identification of RAPD markers linked to potato virus $\mathrm{Y}$ resistance gene in tobacco; Bull. CORESTA, Yokohama, 1996, Abstr. P9, p. 160.

21. Johnson S.E.: Identification of RAPD markers to the black shank resistance gene in Coker 371Gold; Bull. CORESTA, Yokohama, 1996, p.88-89.

22. Rufty R., Y.H. Yi and E.A. Wernsman: RAPD markers linked to wildfire resistance in tobacco identified through bulked-segregant analysis; Bull. CORESTA, Montreux, 1997, Abstract AP 63, p.56.

23. Coussirat J.C.: Genetic fingerprinting of tobacco by RAPD: Use of markers to screen somatic hybrids between Nicotiana rustica L; Ann. du Tabac 25, Section 2 (1993) 1-6.

24. Murray H.G. and W.F. Thompson: Rapid isolation of higher molecular weight DNA; Nucl. Acids Res. 8 (1980) 4321.

25. Doyle J.J. and E.E. Dickson: A rapid DNA isolation procedure for small quantities of fresh leaf tissue; Phytochem. Bull. 19 (1987) 11.

26. Edwards K., C. Johnstone and C. Thompson: A simple and rapid method for the preparation of plant genomic DNA for PCR analysis; Nucleic Acids Res 19 (1991) 1349.
27. Goring D.R., L. Thomson and S.J. Rothstein: Transformation of a partial nopaline Synthase gene into tobacco suppresses the expression of a resident wild-type gene; Proc. Natl. Acad. Sci. USA 88 (1991) 1770-1779.

28. Kang F.Y., A. Van Deynze, and K.P. Pauls: Random amplified polymorphic DNA (RAPD) analysis; in: Methods in plant molecular biology and biotechnology, edited by B.R. Glick and J.E. Thompson, CRC Press, Inc., 1993, pp. 287-301.

29. Vroh B.I., P. du Jardin, G. Mergeai and J.P. Baudoin: Optimization et application de la RAPD (Random Amplified Polymorphic DNA) dans un programme de selection recurrent chez le cotonnier (Gossypium spp.); Biotechnol. Agron. Environ. 1 (1997) 142-150.

30. Eckert K.A. and T.A. Kunkel: The fidelity of DNA polymerases used in the polymerase chain reaction; in: PCR a pratical approach, Vol. I, edited by M.J. Mc. Pherson, P. Quirke and G.R. Taylor, Oxford University Press, 1991, pp. 225-244.

31. Michelmore R.W., R.V. Kesseli, D.M. Francis, M. G. Fortin, I. Paran, and C.H. Yang: Strategies for cloning plant disease resistance genes; in: Molecular plant pathology, a pratical approch, Vol. II, edited by S.J. Gurr, M.J. Mc. Pherson, and D.J. Bowles, Oxford University Press, 1992, pp. 231-288.

32. Abo-Elwafa A., K. Murai. and T. Shimada: Intraand inter-specific variations in Lens revealed by RAPD markers; Theor. Appl. Genet. 90 (1995) 335-340.

33. Alvarez M.T., P Garcia. and M. Perez de la Vega: RAPD polymorphism in Spanish lentil landraces and cultivars; J. Genet. Breed. 51(1997) 91-96.

Address for correspondence:

Istituto Sperimentale per il Tabacco,

via P. Vitiello no 66,

84018 Scafati (SA), Italy. 